\title{
Combining Ability Analysis Using Diallel Crosses among Eight Inbred Lines of maize under Two Planting Dates
}

\author{
Ferial.M. Turk, M. El. M. El-Badawy,A.A.A. El Hosary, S.A.S Mehasen \\ Agron.Dept., Fac. of Agric. Moshtohor, Benha Univ. \\ Corresponding Author: ahmed.alhossary@fagr.bu.edu.eg
}

\begin{abstract}
A half diallel cross between 8 inbred lines of maize was evaluated at two different planting dates for nine quantitative characters. Planting dates and crosses mean squares were significant for all studied traits. Mean squares due to crosses $\mathrm{x}$ planting dates were significant obtained for most studied traits. General (GCA) and specific (SCA) combing ability mean squares were significant for all traits. High ratios which largely exceeded the unity for days to $50 \%$ tassling and silking, plant height, ear height, no of rows/ ear, no of grains / row and 100 kernel weight were obtained, indicating that a large part of the total genetic variability associated with these traits indicates that of additive and additive by additive gene action. For remain cases, GCA/SCA ratios were less than unity, therefore, it could be summarized that the most percentage of the total genetic variability for these traits was due to non-additive gene action. For plant height, ear height and grain yield/ plant, the ratio of SCA x D/SCA was higher than GCA x D/GCA. This result indicates that non- additive effects were more influenced by sowing date than additive genetic effects for this trait. P1 seemed to be the best general combiner for early maturity, short plants, low ear position, grain yield/plant and some of its components in the combined analysis of both sowing dates. The parental combination P1xP3, P1xP5, P1xP7, P2xP4, P2xP5, P2xP7, P3xP4, $\mathrm{P} 3 x \mathrm{P} 5, \mathrm{P} 3 \mathrm{xP} 6, \mathrm{P} 3 \mathrm{xP} 4, \mathrm{P} 6 \mathrm{xP7}$ and , P7xP8 for grain yield/plant exhibited significant positive $\hat{S}_{i j}$ effects being $13.54,14.68,12.79,21.81,21.61,9.15,21.64,27.34,7.36,6.37$ and 33.49 , respectively
\end{abstract}

Key words: Maize, Combining ability, planting date, GxE.

\section{Introduction}

Maize (Zea mays L.) is the most important cereal crops in the world and Egypt due to its vast grown area. It ranked $3^{\text {rd }}$ cereal crop in the world, after wheat and rice. It is essential for human and animal fed. Also, it used for industrial purposes such as manufacturing starch and cooking oils. In 2018 the corn grown area in Egypt was 0.76 Million hectares (1.76 million feddans) with an annual grain production of 6 Million metric tons and an average productivity of 8 ton ha $^{-1}$ (23.8 ardabs/feddan). (One feddan; fed $=4200 \mathrm{~m}^{2}$ and one ardab; $\operatorname{ard}=140 \mathrm{Kg}$ ). (USDA 2018).

Maximizing food and agricultural production, depends mainly on promoting high yielding maize hybrids to cover the mounting consumption of maize. This depends mostly on producing new hybrid of maize across breeding programs. To carry out a successful breeding program, the breeder should have enough knowledge about the type and relative amount of genetic variance components and their interactions by environment for different attributes.

Diallel cross is an important to produce superior hybrids and both types of combining ability helps breeder to identify the most appropriate parents and provide sufficient genetic information on the inheritance of traits. In this regard, highly general combining ability (GCA) and specific combining ability (SCA) effects leading to high heterosis were asserted by El-Hosary (2015), Girma et al (2015),
Al-Naggar et al (2016) and Al-Naggar et al (2017 a and b)

The quantitative characters are extremely affected by the environment, and the amount of such effect increases with the increase in the number of predominant genes. Thus, expression of a specific character which controlled by several loci were display greater genotype $\mathrm{x}$ environment (GxE) interaction. Singh (1973 and 1979) and Waniet al(2017) reported that the GxEinteraction variance is very important to detect stable genotypes.

Diallel mating schema used in large scale in determine combining ability analyses in maize breeding programs to locate the combining ability types. Furthermore, the magnitude of genetic components for a certain trait would depend mainly upon the environmental flection under which the breeding populations will be tested. Thus, differences due to GCA and SCA are associated with the type of gene action implicated.

Variance for GCA contains additive part while that of SCA includes non-additive part of total variance emerging mostly from dominance and epistatic deviations (El-Hosary (2015) and Izhar and Chakraborty 2013).

The main objectives of this investigation are to : 1) determine hybrid performance for the studied parental combination.2) estimate the amount of superiority over the check hybrid Hytech 2031. and3) establish the magnitude of both general combining ability (GCA) and specific combining 
ability (SCA) effects and their interaction with two planting date.

\section{Materials and Methods}

Eight white inbred lines were used as parents in this study. Moshtohor $\mathrm{P}_{1}$ (T.S M1), $\mathrm{P}_{2}$ (T.S M2), $\mathrm{P}_{3}$ (T.S M3), $\mathrm{P}_{4}$ (T.S M4), $\mathrm{P}_{5}$ (T.S M5), $\mathrm{P}_{6}$ (T.S M6), $\mathrm{P}_{7}$ (T.S M7), and $\mathrm{P}_{8}$ (T.S M1) were obtained by Dr. Maged Hamouda at Techno seeds company. In the first season (summer 2018) the eightnewinbred lines were sown in three different planting dates to avoid differences in flowering time and to secure enough hybrid seed. All possible combinations without reciprocals were made between the eight inbred lines by hand method giving a total of 28 crosses. In the second season (summer 2019), two adjacent experiments were conducted at the two planting dates:9th June and 18th July. In each experiment the $28 \mathrm{~F}_{1}$ hybrids as well as two check SC Hytech 2031were grown in a randomized complete block design with three replications. Each plot consisted of two ridges of $5 \mathrm{~m}$ length and $70 \mathrm{~cm}$ width. Hills were spaced by $25 \mathrm{~cm}$ with two kernels per hill and later thinned to one plant per hill. The dry method of sowing was used. The first irrigation was given after about 21 days from sowing. The cultural practices were followed as recommended for ordinary maize field in the area. Random sample of 10 guarded plants in each plot was taken to evaluate silking and tasseling dates (days) in $50 \%$ of the plant silked or tasseled, plant height $(\mathrm{cm})$, ear height $(\mathrm{cm})$, No. of kernels/row, No. of rows/ear, 100-kernel weight, grain yield/plant which was adjusted for $15.5 \%$ moisture and shelling $\%$.

The obtained data were statistically analyzed for analysis of variance by using computer statistical program MSTAT-C. General and specific combining ability estimates were estimated according to Griffing's (1956) diallel cross analysis designated as method 4 model I for each experiment. The combined analysis of the two experiments was carried out whenever homogeneity of variance was detected (Gomez and Gomez, 1984). Relative superiority according to Singh et al. (2004) and ELHosary (2020) expressed as the percentage deviation of the $F_{1}$ mean performance from S.C. Hytech 2031 was also estimated

\section{Results and Discussion}

The analysis of variance for ordinary analysis over the two experiments for all studied traits is given in Table (1). Planting date mean squares for all traits under study were significant, with mean values in earlybeing higher than those in late planting date for all studied traits.

It coud be concluded that planting dates showed positive effect on the previous traits on maize. Genotypes mean squares were significant for all traits in both sowing dates as well as the combined analysis except for ear diameter in the early sowing date and no of rows/ ear at late sowing date (Table 1). This indicates the wide diversity between the parental materials used in the present study. Significant genotypes $\mathrm{x}$ sowing date mean squares were obtained for planting height, ear height, ear leaf area, ear length, no of grains/ row, 100 kernel weight, ear weight/ plant and grain yield/ plant revealing that the performance of genotypes differed from one sowing date to another.

Remain traits with insignificant Genotype $\mathrm{x}$ planting date was detected reflecting that these hybrids responded similarly to environmental changes. The fluctuation of hybrids from sowing date to another was detected for most traits

Mean performances of $F_{1}$ hybrids, S.C. Hytech 2031 are presented in Table (2).

It is favorable if the single crosses were earlier in flowering than parents to develop early maturity hybrids to avoid damage by borers or other environmental adverse conditions. The parental combinations that incorporated earliness in silking and tasseling dates as well as exhibited superiority over SC Hytech 2031 are plants of those $F_{1}$ hybrids $1 \times 5$ and $2 \times 4$.Earliness in maize is favorable for escaping destructive injuries caused by Sesamia cretica, Chilo simplex and Pyrausta nubilialis. Similar results were reported by El-Hosary and ElBadawy (2005) and El-Hosary et al (2006).

The crosses $2 \times 3,1 \times 5,1 \times 6,1 \times 7,1 \times 8,2 \times 5$ and $3 \times 4$ gave the lowest mean values of plant and ear heights compared with the check hybrids. However, the crosses $3 \times 7$ and $4 \times 6$ gave the highest value for plant height. The choice between taller plants with highest ear and shorter plants with reduced ear height depends on the breeder's objective. From the point of view for the breeder the highest plant gave high biomass is vital for high production on the same time the low ear position is important for resistance to stem lodging.

The cross $3 \times 8,2 \times 4,4 \times 5$ and $2 \times 6$ recorded the highest number of kernels/row, with significant difference from check hybrid 2031 in the combined analysis. The cross $3 \times 8,2 \times 4,4 \times 5$ and $2 \times 6$ recorded the highest number of kernels/row, with significant difference from check hybrid 2031 in the combined analysis. The crosses $2 \times 4,2 \times 7,5 \times 7$ and $6 \times 7$ in early planting date; the crosses $1 \times 3,1 \times 5,1 \times 7,2 \times 5$ and $3 \times 5$ in the late planting date and the combined across them had significant superiority over the check hybrid. These hybrids exhibited significant increase of two or more of traits contributing to grain yield Table (7). 
Table 1. Observed mean squares from ordinary analysis and combining ability for the studied traits in each and across planting dates.

\begin{tabular}{|c|c|c|c|c|c|c|c|c|c|c|c|}
\hline \multirow{3}{*}{ SOV } & \multicolumn{2}{|c|}{ df } & \multicolumn{3}{|c|}{ days to $50 \%$ tasseling } & \multicolumn{3}{|c|}{ days to $50 \%$ silking } & \multicolumn{3}{|c|}{ plant height } \\
\hline & & & Early & & & & & & & & \\
\hline & S. & c. & PL & Late PL & C. & Early PL & Late PL & C. & Early PL & Late PL & C. \\
\hline $\begin{array}{l}\text { planting date } \\
\text { (D) }\end{array}$ & & 1 & & & $\begin{array}{c}490.29 * \\
*\end{array}$ & & & $640.38 * *$ & 33.04 & 7.15 & 20.1 \\
\hline blocks/D. & 2 & 4 & $9.73 * *$ & 1.3 & $5.51 *$ & $8.33 *$ & 0.23 & $4.28^{*}$ & $\begin{array}{c}1267.67 \\
* *\end{array}$ & $\begin{array}{c}1382.28 \\
* *\end{array}$ & $\begin{array}{c}2238.03 \\
* *\end{array}$ \\
\hline Crosses & $\begin{array}{l}2 \\
7\end{array}$ & 27 & $5.24 * *$ & $8.87 * *$ & $11.39 * *$ & $5.37 *$ & $11.47 * *$ & $13.92 * *$ & & & $\begin{array}{c}411.92 * \\
*\end{array}$ \\
\hline Crosses x D & & 27 & & & 2.72 & & & 2.92 & 25.94 & 17.34 & 21.64 \\
\hline Error/D. & $\begin{array}{l}5 \\
4\end{array}$ & $\begin{array}{c}10 \\
8\end{array}$ & 1.81 & 1.68 & 1.75 & 2.14 & 2.08 & 2.11 & $\begin{array}{c}640.58 * \\
*\end{array}$ & $\begin{array}{c}535.80 * \\
*\end{array}$ & $\begin{array}{c}1036.01 \\
* *\end{array}$ \\
\hline GCA & 7 & 7 & $2.42 * *$ & $5.01 * *$ & $6.58 * *$ & $3.01 * *$ & $6.02 * *$ & $8.25 * *$ & $\begin{array}{c}346.25 * \\
*\end{array}$ & $\begin{array}{c}434.49 * \\
*\end{array}$ & $\begin{array}{c}644.51 * \\
*\end{array}$ \\
\hline SCA & $\begin{array}{l}2 \\
0\end{array}$ & 20 & $1.51^{* *}$ & $2.24 * *$ & $2.82 * *$ & $1.36^{*}$ & $3.06^{* * *}$ & $3.38 * *$ & & & 140.37 \\
\hline GCAxD & & 7 & & & 0.85 & & & 0.78 & & & 136.23 \\
\hline SCAxD & & 20 & & & 0.93 & & & 1.04 & 8.65 & 5.78 & 7.21 \\
\hline Error & $\begin{array}{l}5 \\
4\end{array}$ & $\begin{array}{c}10 \\
8\end{array}$ & 0.6 & 0.56 & 0.58 & 0.71 & 0.69 & 0.7 & 1.85 & 1.23 & 1.61 \\
\hline $\begin{array}{l}\text { GCA/SCA } \\
\text { GCAx D /GCA } \\
\text { SCAxD/SCA }\end{array}$ & & & 1.6 & 2.24 & 2.33 & $\begin{array}{l}2.21 \\
0.13 \\
0.33\end{array}$ & 1.97 & $\begin{array}{c}2.44 \\
0.09 \\
0.031\end{array}$ & 33.04 & 7.15 & $\begin{array}{l}20.1 \\
0.14 \\
0.21\end{array}$ \\
\hline SOV & & & Early & Ear heigh & & & o o f rows/ & & & of kernel/r & \\
\hline $\begin{array}{l}\text { planting date } \\
\text { (D) }\end{array}$ & S. & $\begin{array}{l}\text { c. } \\
1\end{array}$ & PL & Late PL & $\begin{array}{c}\mathrm{C} . \\
2325.15 \\
* *\end{array}$ & Early PL & Late PL & $\begin{array}{l}\text { C. } \\
0.86\end{array}$ & Early PL & Late PL & $\begin{array}{c}\text { C. } \\
107.84 * \\
*\end{array}$ \\
\hline blocks/D. & 2 & 4 & $42.86^{* *}$ & $27.08 * *$ & $34.97 * *$ & 0.46 & 82.75 & 41.61 & 0.33 & 2.65 & 1.49 \\
\hline Crosses & $\begin{array}{l}2 \\
7\end{array}$ & 27 & $\begin{array}{c}844.74 * \\
*\end{array}$ & $\begin{array}{c}555.86^{*} \\
*\end{array}$ & $\begin{array}{c}1223.91 \\
* *\end{array}$ & $6.01 * *$ & 7.16 & 8.94 & $37.46 * *$ & $47.60 * *$ & $45.23 * *$ \\
\hline Crosses x D & & 27 & & & $\begin{array}{c}176.69 * \\
*\end{array}$ & & & 4.23 & & & $39.83 * *$ \\
\hline Error/D. & $\begin{array}{l}5 \\
4\end{array}$ & $\begin{array}{c}10 \\
8\end{array}$ & 9.52 & 6.1 & 7.81 & 1.06 & 0.82 & 0.94 & 5.94 & 7.43 & 6.69 \\
\hline GCA & 7 & 7 & $\begin{array}{c}345.34 * \\
*\end{array}$ & $\begin{array}{c}265.21 * \\
*\end{array}$ & 578.55 & $1.43 * *$ & $2.43 * *$ & $2.48 * *$ & $12.60 * *$ & $32.67 * *$ & $19.70 * *$ \\
\hline SCA & $\begin{array}{l}2 \\
0\end{array}$ & 20 & $\begin{array}{c}259.27 * \\
*\end{array}$ & $\begin{array}{c}157.31 * \\
*\end{array}$ & $\begin{array}{c}348.27 * \\
*\end{array}$ & $2.20 * *$ & $2.37 * *$ & $3.15^{* *}$ & $12.45^{* *}$ & $9.99 * *$ & $13.46^{* *}$ \\
\hline $\begin{array}{l}\text { GCAxD } \\
\text { SCAxD }\end{array}$ & & $\begin{array}{c}7 \\
20\end{array}$ & & & $\begin{array}{l}31.99 * * \\
68.31 * *\end{array}$ & & & $\begin{array}{l}1.37 * * \\
1.42 * *\end{array}$ & & & $\begin{array}{l}25.56^{* * *} \\
8.98^{* *}\end{array}$ \\
\hline Error & $\begin{array}{l}5 \\
4\end{array}$ & $\begin{array}{c}10 \\
8\end{array}$ & 3.17 & 2.03 & 2.6 & 0.35 & 0.27 & 0.31 & 1.98 & 2.48 & 2.23 \\
\hline $\begin{array}{l}\text { GCA/SCA } \\
\text { GCAx D /GCA } \\
\text { SCAxD/SCA }\end{array}$ & & & 1.33 & 1.69 & $\begin{array}{c}1.66 \\
0.06 \\
0.2\end{array}$ & 0.65 & 1.02 & $\begin{array}{l}\quad 0.79 \\
0.55 \\
0.45\end{array}$ & 1.01 & 3.27 & $\begin{array}{l}\quad 1.46 \\
0.74 \\
0.67\end{array}$ \\
\hline SOV & & & Early ${ }^{10}$ & -kernel we & & & ain yield/ $p$ & & & Shelling\% & \\
\hline $\begin{array}{l}\text { planting date } \\
\text { (D) }\end{array}$ & S. & $\begin{array}{l}\text { c. } \\
1\end{array}$ & PL & Late PL & $\begin{array}{c}\mathrm{C} . \\
6.96^{* *}\end{array}$ & Early PL & Late PL & $\begin{array}{c}\mathrm{C} . \\
21519.55 \\
* *\end{array}$ & Early PL & Late PL & $\begin{array}{c}\text { C. } \\
13.71 * *\end{array}$ \\
\hline blocks/D. & 2 & 4 & 0.37 & 3.01 & 1.69 & 3.3 & 13.58 & 8.44 & 1.82 & $5.57 * *$ & $3.69 *$ \\
\hline Crosses & $\begin{array}{l}2 \\
7\end{array}$ & 27 & $46.75^{* *}$ & $\begin{array}{c}119.53 * \\
*\end{array}$ & $\begin{array}{c}107.44 * \\
*\end{array}$ & $\begin{array}{c}2798.95 \\
* *\end{array}$ & $\begin{array}{c}3503.85 \\
* *\end{array}$ & $\begin{array}{c}2615.72 * \\
*\end{array}$ & $8.41^{* *}$ & $6.77 * *$ & $9.52 * *$ \\
\hline Crosses $x D$ & & 27 & & & $58.84 * *$ & & & $\begin{array}{c}3687.08^{*} \\
*\end{array}$ & & & $5.67 * *$ \\
\hline Error/D. & $\begin{array}{l}5 \\
4\end{array}$ & $\begin{array}{c}10 \\
8\end{array}$ & 2.54 & 1.98 & 2.26 & 33.37 & 22.4 & 27.88 & 1.53 & 1.99 & 1.76 \\
\hline GCA & 7 & 7 & $12.94 * *$ & $60.27 * *$ & $44.64 * *$ & $\begin{array}{c}1038.70 \\
* *\end{array}$ & $\begin{array}{c}513.05^{*} \\
*\end{array}$ & $853.38^{* *}$ & $1.86^{*}$ & $3.35^{* * *}$ & $3.44 * *$ \\
\hline SCA & $\begin{array}{l}2 \\
0\end{array}$ & 20 & $16.51^{* *}$ & $32.69 * *$ & $32.72 * *$ & $\begin{array}{c}895.98 * \\
*\end{array}$ & $\begin{array}{c}1397.16 \\
* *\end{array}$ & $878.39 * *$ & $3.13^{* *}$ & $1.88^{*}$ & $3.08^{* *}$ \\
\hline GCAxD & & 7 & & & $28.57 * *$ & & & $698.38 * *$ & & & $1.77^{*}$ \\
\hline SCAxD & & 20 & & & $16.48^{* *}$ & & & $\begin{array}{c}1414.75^{*} \\
*\end{array}$ & & & $1.93^{*}$ \\
\hline Error & $\begin{array}{l}5 \\
4\end{array}$ & $\begin{array}{c}10 \\
8\end{array}$ & 0.85 & 0.66 & 0.75 & 11.12 & 7.47 & 9.29 & 0.51 & 0.66 & 0.59 \\
\hline $\begin{array}{l}\text { GCA/SCA } \\
\text { GCAx D /GCA } \\
\text { SCAxD/SCA }\end{array}$ & & & 0.78 & 1.84 & 1.36 & $\begin{array}{l}1.16 \\
0.64 \\
0.50 \\
\end{array}$ & 0.37 & 0.97 & $\begin{array}{c}0.6 \\
1.36 \\
1.61 \\
\end{array}$ & 1.79 & $\begin{array}{l}1.12 \\
0.51 \\
0.63 \\
\end{array}$ \\
\hline
\end{tabular}

$*$ and $* *$ refers to significant $\mathrm{p}<0.05$ and $\mathrm{p}<0.01$, respectively.

$\mathrm{C}$ refer to combined across seasons. 
Table 2. Mean performance of the crosses for all studied traits across environments, grain yield plant ${ }^{-1}$ at both and across planting dates and superiority relative to check hybrid SCHytech 2031 at both and across environments.

\begin{tabular}{|c|c|c|c|c|c|c|c|c|}
\hline $\begin{array}{l}\text { cro } \\
\text { Ss }\end{array}$ & $\begin{array}{c}\text { Days to } 50 \% \\
\text { tasseling (days) }\end{array}$ & $\begin{array}{l}\text { Days to } 50 \% \\
\text { silking (days) }\end{array}$ & $\begin{array}{l}\text { plant } \\
\text { height } \\
(\mathrm{cm})\end{array}$ & $\begin{array}{l}\text { ear } \\
\text { heigh } \\
\text { t } \\
(\mathrm{cm})\end{array}$ & $\begin{array}{l}\text { No of } \\
\text { rows/ ear }\end{array}$ & $\begin{array}{l}\text { No of } \\
\text { kernels/ } \\
\text { row }\end{array}$ & $\begin{array}{c}\text { 100-kernel } \\
\text { weight } \\
\text { (g) }\end{array}$ & $\begin{array}{l}\text { shelli } \\
\text { ng\% }\end{array}$ \\
\hline $1 \times 2$ & 59.83 & 57.17 & 245 & 117.5 & 13.83 & 33.67 & 42.17 & 86.91 \\
\hline $1 \times 3$ & 60.83 & 58 & 295 & $\begin{array}{c}143.3 \\
3\end{array}$ & 14.67 & 37.33 & 44.83 & 85.39 \\
\hline $1 \times 4$ & 59.5 & 59 & 286.67 & 140 & 12.83 & 36.33 & 42.83 & 90.18 \\
\hline $1 \times 5$ & 58.67 & 55.5 & 276.67 & $\begin{array}{c}126.6 \\
7\end{array}$ & 12.33 & 34.83 & 44 & 87.99 \\
\hline $1 \times 6$ & 60.33 & 57.5 & 279.17 & $\begin{array}{c}120.8 \\
3\end{array}$ & 14.83 & 30.67 & 41.33 & 85.99 \\
\hline $1 \times 7$ & 61 & 58.17 & 273.33 & 122.5 & 13.33 & 38 & 48.17 & 86.65 \\
\hline $1 \times 8$ & 59.67 & 56.83 & 276.67 & $\begin{array}{c}125.8 \\
3\end{array}$ & 13.33 & 33.5 & 44.67 & 86.68 \\
\hline $2 \times 3$ & 59.83 & 57.67 & 301.67 & $\begin{array}{c}138.3 \\
3\end{array}$ & 13.33 & 39.67 & 36.67 & 90.08 \\
\hline $2 \times 4$ & 58.67 & 56.17 & 292.5 & $\begin{array}{c}129.1 \\
7\end{array}$ & 14.33 & 40 & 44.17 & 84.2 \\
\hline $2 \times 5$ & 59 & 56.33 & 273.33 & $\begin{array}{c}128.3 \\
3\end{array}$ & 13 & 38.67 & 42.17 & 84.61 \\
\hline $2 \times 6$ & 61.5 & 58 & 288.33 & $\begin{array}{c}151.6 \\
7\end{array}$ & 13.17 & 41 & 44.5 & 83.55 \\
\hline $2 \times 7$ & 60.5 & 57.33 & 301.67 & $\begin{array}{c}148.3 \\
3\end{array}$ & 14.33 & 38.17 & 40.33 & 86.29 \\
\hline $2 \times 8$ & 60.33 & 57.17 & 276 & $\begin{array}{c}121.6 \\
7\end{array}$ & 13.83 & 35.33 & 39.17 & 83.84 \\
\hline $3 \times 4$ & 59.17 & 56.83 & 238.33 & $\begin{array}{c}105.8 \\
3\end{array}$ & 15.17 & 36 & 37 & 85.42 \\
\hline $3 \times 5$ & 60.5 & 57.5 & 300 & 135 & 15.67 & 36.67 & 44.17 & 90.58 \\
\hline $3 \times 6$ & 60.67 & 58.5 & 276.67 & 140 & 13.17 & 39.67 & 42.5 & 90.05 \\
\hline $3 \times 7$ & 61.33 & 58.17 & 316.67 & $\begin{array}{c}161.6 \\
7\end{array}$ & 12.17 & 35.67 & 38.5 & 91.21 \\
\hline $3 \times 8$ & 63.33 & 60.67 & 308.33 & $\begin{array}{c}153.3 \\
3\end{array}$ & 14 & 41.67 & 36.33 & 88.5 \\
\hline $4 \times 5$ & 64.33 & 60.67 & 306.67 & 145 & 13.17 & 40.07 & 32.7 & 88.73 \\
\hline $4 \times 6$ & 62.67 & 59.83 & 320 & $\begin{array}{c}166.6 \\
7\end{array}$ & 11.67 & 36 & 44.83 & 87.32 \\
\hline $4 \times 7$ & 63.83 & 60.83 & 300 & 155 & 13.67 & 38.33 & 36 & 81.84 \\
\hline $4 \times 8$ & 62.17 & 59.33 & 301.67 & 140 & 13 & 32.67 & 42.5 & 89.85 \\
\hline $5 \times 6$ & 62.67 & 59.33 & 301.67 & 132.5 & 12.83 & 34.33 & 47.83 & 83.75 \\
\hline $5 \times 7$ & 62.33 & 59.5 & 303.33 & 150 & 12.5 & 38.33 & 36.83 & 84.62 \\
\hline $5 \times 8$ & 62 & 59.17 & 296.67 & $\begin{array}{c}128.3 \\
3\end{array}$ & 15.17 & 33.67 & 34.17 & 85.62 \\
\hline $6 \times 7$ & 61.83 & 58.33 & 308.33 & $\begin{array}{c}151.6 \\
7\end{array}$ & 12.17 & 39.33 & 40.83 & 84.64 \\
\hline $6 \times 8$ & 61.83 & 59 & 310 & 145 & 16.17 & 39 & 32.83 & 86.53 \\
\hline $7 \times 8$ & 60.67 & 58 & 295.83 & $\begin{array}{c}136.6 \\
7\end{array}$ & 16.33 & 35.33 & 40.33 & 89.35 \\
\hline $\begin{array}{l}\text { Che } \\
\text { ck }\end{array}$ & 63 & 59.83 & 316.67 & 130 & 13.33 & 38.67 & 38.83 & 86.5 \\
\hline $\begin{array}{l}\text { LS } \\
\text { D } 5\end{array}$ & 2.34 & 2.48 & 8.27 & 4.01 & 1.57 & 4.19 & 2.44 & 4.63 \\
\hline $\begin{array}{l}\text { LS } \\
\text { D } 1\end{array}$ & 3.1 & 3.29 & 10.97 & 5.32 & 2.08 & 5.56 & 3.23 & 6.21 \\
\hline
\end{tabular}


Table 2. Cont.

\begin{tabular}{|c|c|c|c|c|c|c|}
\hline \multirow{3}{*}{ cross } & \multicolumn{3}{|c|}{ Grain yield/ plant (g) } & \multicolumn{3}{|c|}{ Relative superiority over SC Hytech 2031} \\
\hline & \multirow[b]{2}{*}{ P L1 } & \multirow[b]{2}{*}{ PL 2} & \multirow[b]{2}{*}{ Comb. } & \multicolumn{3}{|c|}{$\mathrm{H} \%$} \\
\hline & & & & P L1 & PL 2 & Comb. \\
\hline $1 \times 2$ & 210.33 & 159.33 & 184.83 & $17.2 * *$ & $11.16^{* *}$ & $14.52 * *$ \\
\hline $1 \times 3$ & 214.67 & 208.67 & 211.67 & $19.61 * *$ & $45.58 * *$ & $31.14 * *$ \\
\hline $1 \times 4$ & 217.2 & 136 & 176.6 & $21.03 * *$ & -5.12 & $9.42 * *$ \\
\hline $1 \times 5$ & 217.67 & 200.33 & 209 & $21.29 * *$ & $39.77 * *$ & $29.49 * *$ \\
\hline $1 \times 6$ & 186.67 & 185 & 185.83 & 4.01 & $29.07 * *$ & $15.14 * *$ \\
\hline $1 \times 7$ & 195.8 & 242.67 & 219.23 & $9.1 * *$ & $69.3 * *$ & $35.83 * *$ \\
\hline $1 \times 8$ & 215 & 164.33 & 189.67 & $19.8 * *$ & $14.65 * *$ & $17.51 * *$ \\
\hline $2 \times 3$ & 168 & 153.67 & 160.83 & $-6.39 *$ & $7.21 * *$ & -0.35 \\
\hline $2 \times 4$ & 236.2 & 184.33 & 210.27 & $31.61 * *$ & $28.6 * *$ & $30.28 * *$ \\
\hline $2 \times 5$ & 220.67 & 211.67 & 216.17 & $22.96 * *$ & $47.67 * *$ & $33.93 * *$ \\
\hline $2 \times 6$ & 162 & 228 & 195 & $-9.73 * *$ & $59.07 * *$ & $20.82 * *$ \\
\hline $2 \times 7$ & 245 & 186.67 & 215.83 & $36.52 * *$ & $30.23 * *$ & $33.73 * *$ \\
\hline $2 \times 8$ & 195.67 & 195 & 195.33 & $9.03 * *$ & $36.05 * *$ & $21.02 * *$ \\
\hline $3 \times 4$ & 194.73 & 205 & 199.87 & $8.51^{* *}$ & $43.02 * *$ & $23.83 * *$ \\
\hline $3 \times 5$ & 208.33 & 215 & 211.67 & $16.08 * *$ & $50 * *$ & $31.14 * *$ \\
\hline $3 \times 6$ & 208.33 & 166.67 & 187.5 & $16.08 * *$ & $16.28 * *$ & $16.17 * *$ \\
\hline $3 \times 7$ & 201.67 & 131.67 & 166.67 & $12.37 * *$ & $-8.14 * *$ & 3.26 \\
\hline $3 \times 8$ & 214.67 & 142.67 & 178.67 & $19.61 * *$ & -0.47 & $10.7 * *$ \\
\hline $4 \times 5$ & 93 & 241.07 & 167.04 & $-48.18 * *$ & $68.19 * *$ & 3.49 \\
\hline $4 \times 6$ & 180.67 & 156.67 & 168.67 & 0.67 & $9.3 * *$ & 4.5 \\
\hline $4 \times 7$ & 198.33 & 135.67 & 167 & $10.51 * *$ & -5.35 & 3.47 \\
\hline $4 \times 8$ & 186 & 150 & 168 & 3.64 & 4.65 & 4.09 \\
\hline $5 \times 6$ & 182.33 & 144 & 163.17 & 1.6 & 0.47 & 1.09 \\
\hline $5 \times 7$ & 227.33 & 133 & 180.17 & $26.67 * *$ & $-7.21 * *$ & $11.63 * *$ \\
\hline $5 \times 8$ & 153 & 140.67 & 146.83 & $-14.75^{* *}$ & -1.86 & $-9.03 * *$ \\
\hline $6 \times 7$ & 225.67 & 164 & 194.83 & $25.74 * *$ & $14.42^{* *}$ & $20.71 * *$ \\
\hline $6 \times 8$ & 190.87 & 157 & 173.93 & $6.35^{*}$ & $9.53 * *$ & $7.77 * *$ \\
\hline $7 \times 8$ & 234.4 & 211.67 & 223.03 & $30.61 * *$ & $47.67 * *$ & $38.19 * *$ \\
\hline Check & 198.8 & 178 & 188.4 & & & \\
\hline LSD 5 & 9.38 & 7.69 & 8.53 & & & \\
\hline LSD 1 & 12.44 & 10.19 & 11.32 & & & \\
\hline
\end{tabular}

Heterosis:

Relative superiority relative to $\mathrm{SC}$ Hytech 2031 expressed as the percentage deviation of $F_{1}$ mean performance from each of S.C. Hytech 2031 values for grain yield/plant are presented in Table (2). Concerning grain yield/plant ,fourteen, eleven and nine crosses expressed significant and positive heterotic effects in early, late sowing date as well as the combined analysis relative to S.C. Hytech 2031. However, most desirable heterotic effects were detected for the crosses $1 \times 3,1 \times 5,1 \times 7,2 \times 4,2 \times 5,2 \times 7$,
$3 \times 4,3 \times 5$ and $7 \times 8$ in a combined across sowing date. Also, the cross $7 \times 8$ give the highest heterotic value in the combined analysis being $18.38 \%$.

Hence, it could be concluded that these crosses offer possibility for improving grain yield in maize. Several investigators reported high heterosis for yield of maize; i.e. Nawar et al. (1998), ElBagoury et al. (2004), Nawar et al. (2002), and ElHosary et al. (2006). 


\section{Combining ability}

The analysis of variance for combining ability at the combined analysis for all the studied traits is presented in Table (1). The variance of general combining ability includes the additive and additive $\mathrm{x}$ additive genetic portion. While, specific combining ability represents the non additive genetic portion of the total variance arising largely from dominance and epistatic deviations. The mean squares due to general and specific combing ability were highly significant for all traits.

If both general and specific combining ability mean squares are significant, one may ask which type and or types of gene action are important in determining the performance of single- cross progeny. To overcome such situation the size of mean squares can be used to assume the relative importance of both types of combining ability. For all traits general and specific combing ability mean squares were highly significant in both sowing dates as well as the combined data. Hence, GCA/SCA ratio was used as measure to reveal the nature of genetic variance involved

For days to $50 \%$ tassling and silking, plant height, ear height, no of rows/ ear, no of grain / row and 100 kernel weight, high ratios which largely exceeded the unity were obtained, indicating that large part of the total genetic variability associated with these traits was additive and additive by additive gene action.

grain yield/ plant, showed GCA/SCA ratios less than unity. Therefore, it could be concluded that the large portion of the total genetic variability associated with these traits is due to non-additive gene action. The largest heterotic magnitude expressed by the previous traits as the deviation of particular $F_{1}$ mean performance from check S.C. Hytech 3031. May strengthened the conclusion about the importance of non-additive gene effects in their inheritance. Similar results were reported by ElHosary and El-Badawy (2005), Mosa and Motawei (2005), Soliman et al. (2005) and ElHosary et al. (2006)

The mean squares of interaction between sowing dates and both types of combining ability were significant for plant height, ear height, no of rows/ ear, no of grains/ row, 100-kernel weight and grain yield/ plant. Such results showed that the magnitude of all types of gene action varied from sowing date to another. It is fairly evident that the ratio for GCA $x$ D/GCA was higher than ratio of SCA $x$ D/SCA for no of rows/ ear, no of grains/ row and 100-kernel weight. This result indicated that additive effects were more influenced by the environmental conditions than non- additive effects. The genetic variance was previously reported to be mostly due to non-additivefor Plant, ear heights by Amer (2003); no. of grains/row by Amer (2003), and Shafey et al. (2003) and grain yield/plant by Mosa (2003), El-Hosary and El-Badawy (2005); and El-Hosary et al. (2006). On the other hand, the additive genetic variance was previously reported to be the most prevalent for earliness by Dubey et al. (2001); Amer (2003); El-Hosary and El-Badawy (2005), and El-Hosary et al. (2006); 100-kernel weight by Dubey et al. (2001), andEl-Hosary and El-Badawy (2005).

For plant height, ear height and grain yield/ plant, the ratio of SCA x D/SCA was higher than GCA $x$ D/GCA. This result indicated that nonadditive effects were more influenced by sowing date than additive genetic effects for this trait. This conclusion is in well agreement with those reported by Gilbert (1958). These results are in the same line of Amer (2003), Abdel-El-Hosary and El-Badawy (2005), and El-Hosary et al. (2006)

General combining ability effects:

Estimations of GCA effects $\left(\hat{g}_{i}\right)$ for individual parental inbred lines for each trait in the combined analysis are presented in Table (3) General combining ability effects estimated herein differ significantly from zero. High positive values would be of interest under all traits in question except silking, and tassling dates as well as plant and ear heights where high negative effects would be useful from the breeder's point of view.

The parental inbred line no. 1 exhibited significant negative $\left(\hat{g}_{i}\right)$ effects for; tassling, silking dates and ear height across planting dates, indicating that this inbred line could be considered as good combiner for developing early and resistance to lodging genotypes. Also, it gave significant $\left(\hat{g}_{i}\right)$ effects for 100-kernel weight, and grain yield/ plant. The parental inbred line no. 2 showed significant negative $\left(\hat{g}_{i}\right)$ effects for tasseling, silking and plant and ear heights, indicating that this line could be considered as good combiner for developing early, short genotypes. Earliness of inflorescence is required for developing early maturing season to escape corn pest and shorter plant and ear heights are required for lodging resistance. Also, it gave significant positive $\left(\hat{g}_{i}\right)$ effects for 100-kernel weight, grain yield/ plant across planting date;

The parental inbred line no. 3 seemed to be good combiner for no of kernels/ row. On the contrarily, it expressed significant undesirable or insignificant $\left(\hat{g}_{i}\right)$ effects for the rest traits. The parental inbred line no. 4 seemed to be good combiner for no of kernels/ row and ear length at late planting date. However, it gave undesirable $\left(\hat{g}_{i}\right)$ effects for other traits.

The parental inbred line no. 6 seemed to be the best combiner for 100-kernel weight.The parental inbred line no. 7 seemed to be best combiner for; grain yield/ plant.The parental inbred line no. 8 behaved as the best combiner for no of rows/ ear. It 
is worth noting that the inbred line which possessed high $\left(\hat{g}_{i}\right)$ effects for grain yield per plant showed the same effect for one or more of the traits contributing to grain yield.

Table 3. Estimates of general combining ability effects of nine inbred lines for all the studied traits across the two planting dates.

\begin{tabular}{|c|c|c|c|c|c|c|c|c|c|}
\hline parent & $\begin{array}{l}\text { Days to } \\
50 \% \\
\text { tasseling } \\
\end{array}$ & $\begin{array}{l}\text { Days to } \\
50 \% \\
\text { silking }\end{array}$ & $\begin{array}{l}\text { Plant } \\
\text { height }\end{array}$ & $\begin{array}{l}\text { Ear } \\
\text { heigh } \\
\mathrm{t}\end{array}$ & $\begin{array}{l}\text { No of } \\
\text { rows/ } \\
\text { ear }\end{array}$ & $\begin{array}{l}\text { No of } \\
\text { kernels/ro } \\
\text { w }\end{array}$ & $\begin{array}{l}\text { 100- } \\
\text { kernel } \\
\text { weight }\end{array}$ & $\begin{array}{l}\text { Grain } \\
\text { yield/ } \\
\text { plant } \\
\end{array}$ & $\begin{array}{l}\text { shelli } \\
\text { ng\% }\end{array}$ \\
\hline p1 & $-0.91 * *$ & $-1.24 * *$ & $\begin{array}{c}- \\
17.51 \\
* *\end{array}$ & $\begin{array}{l}- \\
11.42 \\
* *\end{array}$ & -0.14 & $-2.36 * *$ & $3.73 * *$ & $10.00 * *$ & -0.34 \\
\hline $\mathrm{p} 2$ & $-1.3 * *$ & $-1.26 * *$ & $\begin{array}{c}- \\
9.84 * \\
*\end{array}$ & $\begin{array}{l}- \\
\text { *.03* }\end{array}$ & -0.03 & $1.34 *$ & 0.6 & $10.24 * *$ & $\begin{array}{c}- \\
0.79 \\
* *\end{array}$ \\
\hline p3 & -0.05 & -0.26 & -0.15 & $\begin{array}{l}2.05 * \\
*\end{array}$ & 0.36 & $1.37 *$ & $-0.93 * *$ & 0.01 & $\begin{array}{c}0.77 \\
* *\end{array}$ \\
\hline $\mathrm{p} 4$ & $0.84 * *$ & 0.51 & 1.38 & $\begin{array}{l}2.74 * \\
* \\
-\end{array}$ & -0.36 & 0.15 & $-0.93 * *$ & $-9.9 * *$ & 0.31 \\
\hline p5 & 0.06 & 0.38 & $\begin{array}{c}3.47 * \\
*\end{array}$ & $\begin{array}{l}3.23 * \\
*\end{array}$ & -0.22 & -0.32 & -0.62 & $-3.8 * *$ & -0.46 \\
\hline p6 & 0.48 & $0.71 *$ & $\begin{array}{c}7.77 * \\
*\end{array}$ & $\begin{array}{l}7.19 * \\
*\end{array}$ & -0.33 & 0.25 & $1.51 * *$ & $-7.98 * *$ & 0.13 \\
\hline p7 & 0.45 & $0.71 *$ & $\begin{array}{c}10.27 \\
* *\end{array}$ & $\begin{array}{l}10.1 * \\
*\end{array}$ & -0.25 & 0.78 & $-0.77 *$ & $8.32 * *$ & 0.57 \\
\hline p8 & 0.42 & 0.46 & $4.6 * *$ & $-\overline{2.4 * *}$ & $0.97 * *$ & $-1.22 *$ & $-2.6^{* *}$ & $-6.89 * *$ & -0.19 \\
\hline $\begin{array}{l}\text { LSD5 } \\
\%(\text { gi) }\end{array}$ & 0.58 & 0.64 & 2.04 & 1.23 & 0.43 & 1.13 & 0.66 & 2.32 & 0.58 \\
\hline $\begin{array}{l}\text { LSD1 } \\
\text { \%(gi) } \\
\text { LSD5 }\end{array}$ & 0.77 & 0.84 & 2.71 & 1.63 & 0.56 & 1.5 & 0.87 & 3.07 & 0.77 \\
\hline $\begin{array}{l}\% \text { (gi- } \\
\text { gj) }\end{array}$ & 0.88 & 0.96 & 3.08 & 1.85 & 0.64 & 1.71 & 1 & 3.5 & 0.88 \\
\hline $\begin{array}{l}\text { LSD1\%( } \\
\text { gi-gj) }\end{array}$ & 1.16 & 1.28 & 4.09 & 2.46 & 0.85 & 2.27 & 1.32 & 4.64 & 1.17 \\
\hline
\end{tabular}

$*$ and $* *$ refers to significant $\mathrm{p}<0.05$ and $\mathrm{p}<0.01$, respectively.

From the previous result, it could be concluded that the parental inbred lines P1 seemed to be the best general combiner for early maturity, short plants, low ear position, grain yield/plant and some of its components in the combined analysis of both sowing dates.

\section{Specific combining ability:}

Estimation of SCA effects in the 28 crosses for the studied traits over the two planting dates are presented in table (4). The most desirable inter and intra allelic interactions were presented by $\mathrm{P}_{3} \mathrm{XP}_{4}$, and $\mathrm{P}_{2} \mathrm{XP}_{4}$ for days to $50 \%$ tasseling and silking; $\mathrm{P}_{3} \times \mathrm{P}_{4}$, $\mathrm{P}_{3} \mathrm{XP}_{6}, \mathrm{P}_{1} \times \mathrm{P}_{2}$, and $\mathrm{P}_{1} \times \mathrm{P}_{7}$ for plant and ear heights; $3 \times 5$ for no of rows/ ear, $\mathrm{P}_{3} \mathrm{XP}_{8}, \mathrm{P}_{6} \mathrm{XP}_{8}, \mathrm{P}_{1} \mathrm{XP}_{7}$ and
$\mathrm{P}_{4} \mathrm{XP}_{5}$ for No of kernels/ row; $\mathrm{P}_{1} \mathrm{xP}_{7}, \mathrm{P}_{1} \times \mathrm{P}_{8}, \mathrm{P}_{2} \mathrm{XP}_{4}$, $\mathrm{P}_{2} \mathrm{XP}_{6}, \mathrm{P}_{3} \mathrm{XP}_{5}, \mathrm{P}_{4} \times \mathrm{P}_{6}, \mathrm{P}_{4} \times \mathrm{P}_{8}$, and $\mathrm{P}_{7} \times \mathrm{P}_{8}$ for 100 -kernel weight. The parental combination $\mathrm{P}_{1} \times \mathrm{P}_{3}, \mathrm{P}_{1} \times \mathrm{P}_{5}$, $\mathrm{P}_{1} \mathrm{XP}_{7}, \mathrm{P}_{2} \mathrm{XP}_{4}, \mathrm{P}_{2} \mathrm{XP}_{5}, \mathrm{P}_{2} \mathrm{XP}_{7}, \mathrm{P}_{3} \mathrm{xP}_{4}, \mathrm{P}_{3} \mathrm{xP}_{5}, \mathrm{P}_{3} \mathrm{XP}_{6}$, $\mathrm{P}_{3} \times \mathrm{P}_{4}, \mathrm{P}_{6} \mathrm{XP}_{7}$ and, $\mathrm{P}_{7} \times \mathrm{P}_{8}$ for grain yield/plant exhibited significant positive $\hat{S}_{i j}$ effects being 13.54, 14.68, $12.79,21.81,21.61,9.15,21.64,27.34,7.36,6.37$ and 33.49 , respectively. These crosses may be prime importance in breeding programmes either towards hybrid maize production or synthetic varieties composed of hybrids which involved the good combiners for the traits in view. 
Table 4. Estimates of specific combining ability effects of all parental combinations for all studied traits across two the planting dates.

\begin{tabular}{|c|c|c|c|c|c|c|c|c|c|}
\hline Crosses & $\begin{array}{l}\text { Days to } 50 \% \\
\text { tasseling }\end{array}$ & $\begin{array}{l}\text { Days to } 50 \% \\
\text { silking }\end{array}$ & $\begin{array}{l}\text { Plant } \\
\text { height }\end{array}$ & $\begin{array}{c}\text { Ear } \\
\text { height }\end{array}$ & $\begin{array}{c}\text { No of } \\
\text { rows/ ear }\end{array}$ & $\begin{array}{c}\text { No of } \\
\text { kernels/row }\end{array}$ & $\begin{array}{l}\text { 100-kernel } \\
\text { weight }\end{array}$ & $\begin{array}{c}\text { Grain yield/ } \\
\text { plant }\end{array}$ & $\begin{array}{c}\text { Shell } \\
\text { ing } \\
\%\end{array}$ \\
\hline P1xP2 & 1.14 & 1.3 & $18.73 * *$ & $\begin{array}{c}- \\
3.93 * *\end{array}$ & 0.29 & -2.24 & $-2.96^{* *}$ & $-23.53 * *$ & $\begin{array}{c}- \\
1.74 * \\
*\end{array}$ \\
\hline P1xP3 & 0.73 & 1.3 & $21.58 * *$ & $\begin{array}{c}14.82^{*} \\
*\end{array}$ & 0.73 & 1.4 & 1.23 & $13.54 * *$ & 0.23 \\
\hline P1xP4 & 0.84 & -0.81 & $11.71^{* *}$ & $\begin{array}{c}10.79 * \\
*\end{array}$ & -0.38 & 1.61 & -0.77 & $-11.62 * *$ & 1.02 \\
\hline P1xP5 & $-1.88 * *$ & $-1.51^{*}$ & -0.37 & $3.43^{*}$ & $-1.02 *$ & 0.58 & 0.09 & $14.68 * *$ & $\begin{array}{c}1.62 * \\
*\end{array}$ \\
\hline P1xP6 & -0.3 & -0.17 & -2.17 & $\begin{array}{c}- \\
12.82 * \\
*\end{array}$ & $1.59 * *$ & -4.16 & $-4.71 * *$ & -4.3 & -1.27 \\
\hline P1xP7 & 0.39 & 0.49 & $10.51 * *$ & $\begin{array}{c}- \\
14.07 * \\
*\end{array}$ & 0.01 & $2.65 * *$ & $4.4 * *$ & $12.79 * *$ & 0.17 \\
\hline P1xP8 & -0.91 & -0.59 & -1.51 & 1.77 & $-1.21^{*}$ & 0.15 & $2.73^{* *}$ & -1.56 & -0.04 \\
\hline $\mathrm{P} 2 \mathrm{xP} 3$ & 0.78 & 0.33 & $20.58 * *$ & $3.43^{*}$ & -0.71 & 0.04 & $-3.8 * *$ & $-37.53 * *$ & -0.22 \\
\hline $\mathrm{P} 2 \mathrm{xP} 4$ & $-1.61^{*}$ & $-1.62 *$ & $9.88 * *$ & $\overline{-}^{-} \cdot 3^{* *}$ & $1.01 *$ & 1.58 & $3.7 * *$ & $21.81 * *$ & $1.63 *$ \\
\hline $\mathrm{P} 2 \mathrm{xP5}$ & -0.66 & -1.15 & $11 . \overline{37} * *$ & -1.29 & -0.46 & 0.72 & 1.39 & $21.61 * *$ & 0.5 \\
\hline P2xP6 & 0.59 & 1.02 & -0.67 & $\begin{array}{c}11.63 * \\
*\end{array}$ & -0.19 & 2.48 & $1.59 *$ & 4.62 & -0.45 \\
\hline $\mathrm{P} 2 \mathrm{xP7}$ & -0.05 & 0.02 & $10.16^{* *}$ & $5.38 * *$ & 0.9 & -0.88 & -0.3 & $9.15^{* *}$ & $\begin{array}{c}1.78 * \\
*\end{array}$ \\
\hline P2xP8 & -0.19 & 0.1 & $-9.84 * *$ & $\begin{array}{c}- \\
8.79 * *\end{array}$ & -0.83 & -1.71 & 0.37 & 3.87 & -1.5 \\
\hline $\mathrm{P} 3 \times \mathrm{x} 4$ & $-2.19 * *$ & $-2.12^{* *}$ & $53.98 * *$ & $\begin{array}{c}- \\
36.85 * \\
*\end{array}$ & $1.45^{* *}$ & -2.44 & $-1.94 * *$ & $21.64 * *$ & $1.49 *$ \\
\hline $\mathrm{P} 3 \mathrm{xP5}$ & -0.75 & -0.65 & 5.6 & -1.71 & $1.81 * *$ & -1.31 & $4.92 * *$ & $27.34 * *$ & 0.61 \\
\hline P3xP6 & -0.16 & -0.81 & $22.04 * *$ & $\begin{array}{c}- \\
7.12^{*} *\end{array}$ & -0.58 & 1.12 & 1.12 & $7.36 * *$ & 0.62 \\
\hline P3xP7 & -0.47 & -0.15 & $15.46^{* *}$ & $\begin{array}{c}11.63 * \\
*\end{array}$ & $-1.66^{* *}$ & -3.41 & -0.6 & $-29.78 * *$ & -0.71 \\
\hline P3xP8 & $2.06^{* *}$ & $2.1^{* *}$ & $12.8^{* *}$ & $\begin{array}{c}15.79 * \\
*\end{array}$ & $-1.05^{*}$ & $4.59 * *$ & -0.93 & -2.57 & 0.95 \\
\hline P4xP5 & $1.53 *$ & 2.41 & $10.74 * *$ & $7.6^{* *}$ & 0.04 & $3.31 *$ & $-6.55^{* *}$ & $-7.39 * *$ & -1.17 \\
\hline P4xP6 & 0.28 & 0.41 & $19.77 * *$ & $\begin{array}{c}18.85^{*} \\
*\end{array}$ & $-1.35^{* *}$ & -1.33 & $3.45^{* *}$ & -1.57 & 0.25 \\
\hline P4xP7 & $1.31 *$ & $1.58^{*}$ & -2.73 & $4.27 * *$ & 0.56 & 0.47 & $-3.11^{* *}$ & $-19.54 * *$ & $1 . \overline{32} *$ \\
\hline P4xP8 & -0.16 & 0.16 & $4.6^{*}$ & 1.77 & $-1.33^{* *}$ & $-3.19 *$ & $5.23 * *$ & -3.33 & 1.07 \\
\hline P5xP6 & 0.56 & 0.55 & -0.65 & $9 . \overline{-}$ & -0.33 & $-2.53^{*}$ & $6.14^{* *}$ & $-13.17 * *$ & 0.88 \\
\hline P5xP7 & 0.75 & 0.21 & -1.48 & $5.24 * *$ & -0.74 & 0.94 & $-2.58 * *$ & $-12.48^{* *}$ & -0.89 \\
\hline P5xP8 & 0.45 & 0.13 & -2.48 & $3.93 * *$ & 0.7 & -1.72 & $-3.41^{* *}$ & $-30.59 * *$ & $1.57 *$ \\
\hline P6xP7 & -0.83 & -0.62 & -0.79 & $\begin{array}{c}- \\
3.51^{* *}\end{array}$ & $-0.96^{*}$ & 1.37 & -0.71 & $6.37 *$ & -0.08 \\
\hline P6xP8 & -0.13 & -0.37 & $6.55^{* *}$ & 2.32 & $1.81 * *$ & $3.04 *$ & $-6.88 * *$ & 0.69 & 0.05 \\
\hline P7xP8 & -1.11 & $-1.54 *$ & $10 . \overline{12} * *$ & $\begin{array}{c}- \\
8.93 * *\end{array}$ & $1.9 * *$ & -1.16 & $2.9 * *$ & $33.49 * *$ & 1.05 \\
\hline $\begin{array}{l}\text { LSD5\%(si } \\
\text { j) }\end{array}$ & 1.28 & 1.41 & 4.51 & 2.71 & 0.94 & 2.51 & 1.46 & 5.12 & 1.29 \\
\hline $\begin{array}{l}\text { LSD1\%(si } \\
\text { j) }\end{array}$ & 1.7 & 1.87 & 5.99 & 3.6 & 1.25 & 3.33 & 1.94 & 6.8 & 1.71 \\
\hline $\begin{array}{l}\text { LSD5\%(si } \\
\text { j-sik) }\end{array}$ & 1.96 & 2.15 & 6.9 & 4.14 & 1.44 & 3.83 & 2.23 & 7.83 & 1.97 \\
\hline $\begin{array}{l}\text { LSD1\%(si } \\
\text { j-sik) }\end{array}$ & 2.6 & 2.85 & 9.15 & 5.49 & 1.91 & 5.08 & 2.96 & 10.38 & 2.61 \\
\hline $\begin{array}{l}\text { LSD5\%(si } \\
\text { j-ski) }\end{array}$ & 1.75 & 1.92 & 6.17 & 3.71 & 1.29 & 3.43 & 1.99 & 7 & 1.76 \\
\hline $\begin{array}{l}\text { LSD1\%(si } \\
\text { j-ski) }\end{array}$ & 2.32 & 2.55 & 8.18 & 4.91 & 1.71 & 4.55 & 2.65 & 9.29 & 2.33 \\
\hline
\end{tabular}

$*$ and $* *$ refers to significant $\mathrm{p}<0.05$ and $\mathrm{p}<0.01$, respectively. 


\section{References}

Al-Naggar, A.M.M., M.M.M. Atta, M.A. Ahmed and A.S.M. Younis (2016).Mean performance, heterobeltiosis and combining ability of corn ( $\mathrm{Zea}$ mays L.) agronomic and yield traits under elevated plant density. J Appl. Life Sci. Int. 7(3):1-20.

Al-Naggar, A.M.M., R. Shabana, M. S. Hassanein , T. A. Elewa, A.S.M. Younis and A.M.A. Metwally (2017a). The effect of increasing plant density on performance and heterobeltiosis in maize testcrosses among 23 inbreds and three testers. J. Archives of Cur. Res. Int. 8(4): 1-14.

Al-Naggar, A.M.M., R. Shabana, M. S. Hassanein , T. A. Elewa, A.S.M. Younis and A.M.A. Metwally $(2017$ b). Estimation of genetic parameters controlling inheritance of maize quantitative traits under different plant densities using Line $\times$ Tester analysis. Asian $\mathbf{J}$ of Adv. Agric. Res. 2(2): 1-12.

Amer, E.A. (2003). Diallel analysis for yield and its components of maize under two different locations. Minufiya J. Agric. Res.28 (5): 13631373.

Amer, E.A. (2005): Estimates of combining ability using diallel crosses among eight new maize inbred lines. j. Aric. Res. Tanta Univ., 31(2) 6773.

Dubey, R.B.; V.N. Joshi and N.K. Pandiya (2001). Heterosais and combining ability for quality, yield and maturity traits in conventional and nonconventional hybrids of maize (Zea mays L.). Indian J. of Gen. and Plant Breed. 61(4): 353355.

El-Bagoury, O.H.; K.A. El-Shouny; H.Y. ElSherbieny and S.A. Al-Ahmad (2004). Estimation of heterosis and its interaction with plant densities in some yellow maize crosses. Arab Universities J. Agric.Sci. 12(1): 201-219.

EL-Hosary, A.A.A. (2020). Diallel analysis of some quantitative traits in eight inbred lines of maize and GGE Biplot analysis for elite hybrids. J. of plant production, Mansoura Univ., Vol. 11(3):375-283.

EL-Hosary, A. A. A. and I. A. I. EL-Fiki (2015). Diallel cross analysis for earliness, yield, its components and resistance to late wilt in maize. Inter. J Agric. Sci. Res. 5( 6):, 199-210

EL-Hosary, A.A. and M.EL.M. EL-Badawy (2005). Heterosis and combining ability in yellow corn (Zea mays L.) under two nitrogen levels. The 11th Conf. Agron., Agron. Dept., Fac. Agric., Assiut Univ., 89-99.

EL-Hosary, A.A.; M.EL.M. EL-Badawy and Y.M. Abdel-tawab (2006). Genetic distance of inbred lines and prediction of maize single-cross performance using RAPD and SSR markers. Egypt. J. Genet. Cytol. 35: 209-224.

El-Hosary, A.A.A. (2015). Genetic analysis of water stress tolerance attributes in $F_{1}$ maize diallel crosses. Egypt. J. Plant Breed. 19 (6): 1765-1781

Gilbert, N.E.G. (1958). Diallel cross in plant breeding heredity, 12: 477-492.

Girma, C.H., A. Sentayehu, T. Berhanu and M. Temesgen (2015). Test cross performance and combining ability of maize (Zea mays L.) inbred lines at Bako, Western Ethiopia. Global J. of Sci. Fron. Res. 15(4)1:1-12.

Gomez, K.N. and A.A. Gomez (1984). Statistical Procedures for Agricultural Research. John.Wiley and Sons. Inc., new york, 2nd ed.

Griffing, B. (1956). Concept of general and specific combining ability in relation to diallel crossing systems. Aus. J. of Biol. Sci. 9: 463-493.

Izhar, T. and M. Chakraborty (2013). Combining ability and heterosis for grain yield and its components in maize inbreds over environments (Zea mays L.). African J. of Agric. Res. 8(25): 3276-3280.

Mosa, H.E. (2003). Combining ability of eight yellow maize (Zea maysL.) inbred lines for different characters in diallel crosses. J. Agric. Res. Tanta Univ., 31(4-A) 604-614.

Mosa, H.E. and A.A. Motawei (2005). Combining ability of resistance to late wilt diseases and grain yield and their relationships under artificial and natural infections in maize. J. Agric. Sci. Mansoura Univ., 30(2): 731-742.

Nawar, A.A.; S.A. El-Shamarka and E.A. ElAbsawy (2002). Diallel analysis of some agronomic traits of maize. J. Agric. Sci. Mansoura Univ., 27 (11): 7203-7213.

Shafey, S.A.; yassien, H.E.; El-Beially, I.E.M.A. and Gad-Alla, O.A.M. (2003). Estimation of combining ability and heterosis effects for groth, earliness and yield in maize (Zea mays L.). J. Agric. Sci. Mansoura Univ., 28 (1): 55-67.

Singh A.K.; Shahi, J.P. and Singh, J.K. (2004).Heterosis in maize. J. Applied Biology 14(1): $1-5$.

Singh, D. (1973). Diallel analysis over different environments-I. Indian $\mathbf{J}$ Genetics and Plant Breed. 33: 127-136.

Singh, D. (1979). Diallel analysis for combining ability over environments. Indian J Genetics and Plant Breed., 39: 383-386.

USDA-FAS, (2018). United States Department of Agriculture, Foreign Agricultural Service. Circular Series January 2018 WAP 1-18

Wani, M.M.A., S.A. Wani, Z.A. Dar, A.A. Lone, I. Abedi and A. Gazal (2017).Combining ability analysis in early maturing maize inbred lines under temperate conditions, Int. J. Pure App. Biosci. 5(2): 456-466. 
تحليل القدرة على التالف باستخدام التهجين التبادلى بين ثمانية سلالات من الذرة الشامية تحت ميعادى زراعه

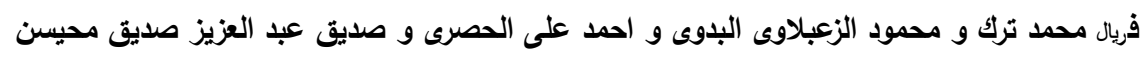

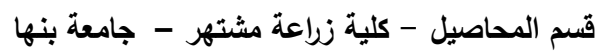

أجرى تقييم الهجن الناتجة من التهجين النصف دائرى لثمانية سلالات من الذره الثامية البيضاء وذلك فى ميعادين مختلفين لتسعة

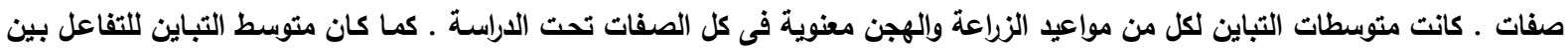

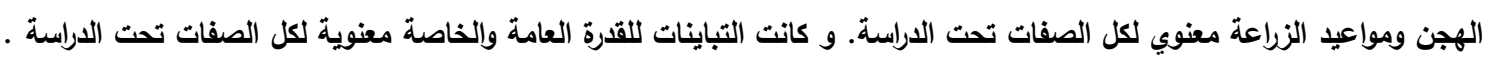

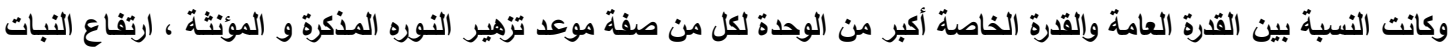

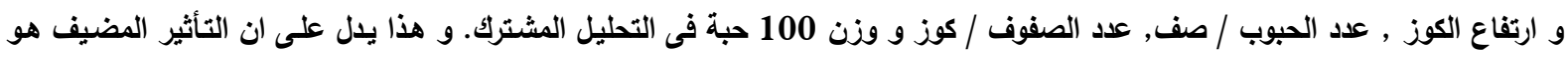

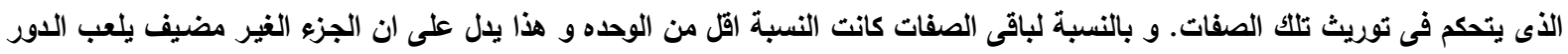

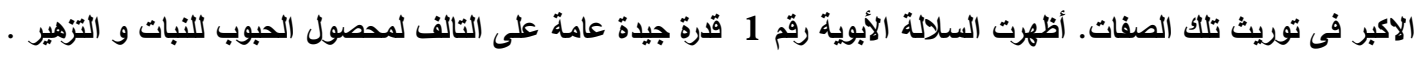
قارة

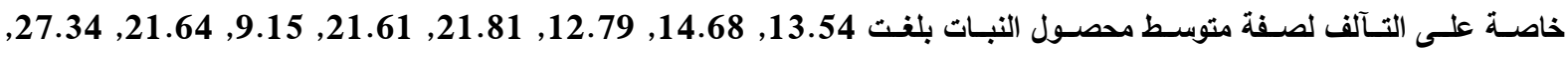
7.36, 7.36, 6.37 و 33.49 على التوالى . 